\title{
THE EFFECT OF ADRENOCORTICOTROPHIC HORMONE IN CONGENITAL ADRENAL HYPERPLASIA WITH VIRILISM AND IN CUSHING'S SYNDROME TREATED WITH METHYL TESTOSTERONE ${ }^{1}$
}

\author{
By ROGER A. LEWIS AND LAWSON WILKINS
}

\begin{abstract}
(From the Department of Pediatrics, Johns Hopkins University School of Medicine, and the Harriet Lane Home of the Johns Hopkins Hospital, Baltimore)
\end{abstract}

(Received for publication October 13, 1948)

There have been several reports of the metabolic effects of adrenocorticotrophic hormone in normal individuals (1-3) and in patients with Addison's disease (1), or panhypopituitarism (4). This trophic hormone has little or no effect upon the metabolic processes in Addison's disease. In normal individuals and in cases of panhypopituitarism there may be profound effects. The changes which occur in the first four hours after a single injection of $25 \mathrm{mg}$. have been studied by Thorn and his coworkers (1). The hematological changes consist of a shift from mononuclear to polymorphonuclear cells and a fall in the number of eosinophils. The metabolic changes are reflected in the urinary excretion. Using creatinine as a reference there is a rise in uric acid, potassium, chloride and sodium.

Browne and his group (2) have studied the effect of large doses, $210 \mathrm{mg}$., of adrenocorticotrophic hormone administered over a 24-hour period to a normal patient. They found oliguria, weight gain, increased excretion of 17 -ketosteroids and neutral reducing lipids, increased excretion of potassium and retention of sodium and chloride. The retention of sodium was apparent during the 24 hours of treatment and more marked during the 24 hours immediately after treatment. There was also an increase in the fasting blood sugar from 98 to 148 mg. \%, glycosuria and a slight rise in the urinary output of nitrogen.

The effect of long range treatment with adrenocorticotrophic hormone has been studied by Thorn and his group, $40 \mathrm{mg}$. a day for four to six days (1) ; by Mason et al., 25-100 mg. a day for 12

1 This work was made possible by a grant from the American Cancer Society for studies on the relationship of the pituitary hormones, thyroid hormone and the steroid hormones of the adrenal glands and gonads to normal and abnormal growth, and by a grant from the Commonwealth Fund for the study of endocrine problems in childhood. days (3) ; and by Albright, Forbes and Bartter, $100 \mathrm{mg}$. a day for six days (4). Mason et al., working with Li's hormone isolated from sheep glands, noted an increase in the excretion of 17 -ketosteroids and neutral reducing lipids but no significant alteration in electrolyte metabolism. However, Thorn's group and Albright, Forbes and Bartter, working with adrenocorticotrophic hormone isolated from hog pituitaries, noted in all cases an increase in the excretion of potassium and decrease in the excretion of sodium and chloride during the administration of the hormone. Although the retention of sodium and chloride was more marked during the second 24 hours of treatment it also occurred consistently during the first 24 hours. Other changes were a rise in the excretion of 17 ketosteroids and neutral reducing lipids, a rise in the fasting blood sugar and an increased excretion of nitrogen. Albright, Forbes and Bartter studied also the effect of adrenocorticotrophic hormone isolated from sheep glands and observed the same effects as with the hog gland preparation.

There have been no reports on the effect of adrenocorticotrophic hormone upon the respiratory quotient and no studies upon its effect in Cushing's syndrome or adrenal hyperplasia with virilization. During the past year we have been able to administer adrenocorticotrophic hormone to one patient with Cushing's syndrome who was being treated with methyl testosterone, and to two girls with congenital adrenal hyperplasia causing pseudohermaphroditism. Studies of the respiratory quotient as well as other metabolic effects and the renal excretion of steroids and electrolytes were performed. The results were quite unusual and despite the small number of cases studied are being reported at this time.

\section{METHODS}

The patients were placed on a constant diet which approximated the normal intake as closely as possible. 
TABLE I

Composition of the diet

\begin{tabular}{|c|c|c|c|c|c|c|c|}
\hline Syndrome & $\begin{array}{l}\text { Carbo- } \\
\text { hydrate }\end{array}$ & Fat & $\begin{array}{l}\text { Pro- } \\
\text { tein }\end{array}$ & $\begin{array}{l}\text { Calo- } \\
\text { ries }\end{array}$ & $\begin{array}{l}\text { So- } \\
\text { dium }\end{array}$ & $\begin{array}{l}\text { Potas- } \\
\text { sium }\end{array}$ & $\begin{array}{c}\text { Chlo- } \\
\text { ride }\end{array}$ \\
\hline $\begin{array}{l}\text { Cushing's } \\
\text { syndrome }\end{array}$ & $\begin{array}{l}g m . \\
265\end{array}$ & $\begin{array}{l}g m . \\
90\end{array}$ & $\begin{array}{l}\mathrm{gm} . \\
90\end{array}$ & $\begin{array}{c}\text { cal. } \\
2,200\end{array}$ & $\begin{array}{c}m . e q . \\
80\end{array}$ & $\begin{array}{c}m . e q . \\
106\end{array}$ & $\begin{array}{c}m . e q . \\
70\end{array}$ \\
\hline $\begin{array}{l}\text { Adrenal hyper- } \\
\text { plasia case B }\end{array}$ & 220 & 80 & 60 & 1,800 & 126 & 85 & 100 \\
\hline $\begin{array}{l}\text { Adrenal hyper- } \\
\text { plasia case D }\end{array}$ & 225 & 80 & 60 & 1,800 & 112 & 84 & 100 \\
\hline
\end{tabular}

The protein, fat and carbohydrate composition of the diet as well as the sodium, potassium and chloride content were calculated from conventional sources. Each patient was given one gram of salt a day to use in seasoning food. This is included in the figures for the diet presented in Table I. The fluid intake was not restricted because of the variable warm weather.

Venous blood was taken for chemical and hematological studies 24 hours before the start of treatment, 48 hours later at the end of the 24-hour treatment period, and again 48 hours later. The respiratory quotient and metabolic rate were determined before breakfast and in the afternoon following a rest period of two to three hours. Urine was collected in 24-hour periods and preserved with thymol and acetic acid.

No studies were made during the first three days on the constant diet. The next three days served as a control period and treatment was given over the next 24 hours. The following 24 -hour period was kept separately to see if there was any carryover or rebound from the treatment period. The following three days served as a post-treatment control period.

The gas analyses were made with a Scholander apparatus (5) on samples of expired air collected in a Douglas bag. Ketosteroid excretion was measured by colorimetric estimation with dinitrobenzene in alkaline alcoholic solution (6). The neutral reducing lipids of the urine were measured by the phosphomolybdic acid color reaction (7) performed on extracts obtained by chloroform extraction and subjected to benzene-water partition (8) but not Girard's separation.2 Other chemical determinations were performed by conventional methods (9) except for sodium and potassium which were estimated with the flame photometer (10). Ordinary technics were used in the hematological studies.

The adrenocorticotrophic hormone used in these experiments was prepared from hog pituitary glands. ${ }^{3}$ Each patient was given eight intramuscular injections of 66 mg. hormone freshly dissolved in $5 \mathrm{cc}$. of normal saline at intervals of three hours. The total dose of $528 \mathrm{mg}$. was equivalent to $83 \mathrm{mg}$. of the standard preparation as assayed by the manufacturers. ${ }^{4}$

\section{CASE HISTORIES}

Cushing's syndrome: The patient (H. L. H. A 35977) was a boy aged $161 / 2$ years. His health was excellent

2 The neutral reducing lipids are generally reported as "11-oxysteroids."

${ }^{3}$ Kindly furnished by Dr. John R. Mote, The Armour Co., Chicago, Illinois.

4 Lot No. 42-B, serial No. G-59703-A, $33 \mathrm{mg}$. equivalent to $5.2 \mathrm{mg}$. standard.

TABLE II

Clinical effects of adrenocorticotrophic hormone

\begin{tabular}{|c|c|c|c|c|c|c|c|}
\hline Syndrome & Period & $\begin{array}{c}\text { Body } \\
\text { weight }\end{array}$ & Pulse & $\begin{array}{c}\text { Blood } \\
\text { pressure }\end{array}$ & $\begin{array}{l}\text { Fluid } \\
\text { output }\end{array}$ & $\begin{array}{l}\text { Metabolic } \\
\text { rate }\end{array}$ & $\begin{array}{l}\text { Respiratory } \\
\text { quotient }\end{array}$ \\
\hline \multirow{4}{*}{$\begin{array}{l}\text { Cushing's } \\
\text { syndrome }\end{array}$} & Control & $\begin{array}{r}\mathrm{kg} . \\
58.9\end{array}$ & $\begin{array}{c}\text { per min. } \\
51\end{array}$ & $\begin{array}{c}m m . / H g \\
150 / 100 \\
\end{array}$ & $\begin{array}{c}c c . \\
1,575\end{array}$ & $\begin{array}{c}\text { cal./day } \\
1,640\end{array}$ & .85 \\
\hline & Treatment & 59.2 & 50 & $130 / 85$ & 1,235 & 1,797 & .76 \\
\hline & Next day & 59.0 & 51 & $185 / 110$ & 1,580 & 1,652 & .89 \\
\hline & Control & 59.2 & 48 & $150 / 100$ & 1,690 & 1,563 & .90 \\
\hline \multirow{4}{*}{$\begin{array}{l}\text { Adrenal hyper- } \\
\text { plasia case B }\end{array}$} & Control & 30.1 & 101 & $108 / 57$ & 760 & 1,270 & .86 \\
\hline & Treatment & 29.8 & 100 & $120 / 55$ & 1,205 & 1,280 & .82 \\
\hline & Next day & 29.9 & 100 & $90 / 50$ & 930 & 1,290 & .87 \\
\hline & Control & 30.0 & 92 & $100 / 55$ & 600 & 1,360 & .84 \\
\hline \multirow{4}{*}{$\begin{array}{l}\text { Adrenal hyper- } \\
\text { plasia case D }\end{array}$} & Control & 29.0 & 93 & $112 / 62$ & 1,040 & 1,474 & - \\
\hline & Treatment & 28.6 & 102 & $120 / 80$ & 790 & 1,416 & .78 \\
\hline & Next day & 28.8 & 90 & $110 / 60$ & .855 & 1,476 & .85 \\
\hline & Control & 28.9 & 90 & $110 / 60$ & 670 & 1,384 & .85 \\
\hline
\end{tabular}


TABLE III

Effect of adrenocorticotrophic hormone upon urinary excretion

\begin{tabular}{|c|c|c|c|c|c|c|c|}
\hline Syndrome & Period & Sodium & Potassium & Chloride & Nitrogen & $\begin{array}{c}\text { Neutral } \\
\text { reducing } \\
\text { lipids }\end{array}$ & $\begin{array}{l}\text { 17-keto- } \\
\text { steroid }\end{array}$ \\
\hline \multirow{4}{*}{$\begin{array}{l}\text { Cushing's } \\
\text { syndrome }\end{array}$} & Control & $\begin{array}{l}\text { m.eq. } \\
142\end{array}$ & $\begin{array}{c}\text { m.eq. } \\
72\end{array}$ & $\begin{array}{c}\text { m.eq. } \\
147\end{array}$ & $\begin{array}{l}g m . \\
13.3\end{array}$ & $\begin{array}{c}m g . \\
0.33\end{array}$ & $\begin{array}{c}\text { mg. } \\
10.4\end{array}$ \\
\hline & Treatment & 39 & 120 & 102 & 13.9 & 1.06 & 24.4 \\
\hline & Next day & 38 & 79 & 66 & 14.5 & 0.69 & 20.2 \\
\hline & Control & 133 & 76 & 117 & 14.0 & 0.33 & 8.3 \\
\hline \multirow{4}{*}{$\begin{array}{l}\text { Adrenal hyper- } \\
\text { plasia case B }\end{array}$} & Control & 95 & 61 & 108 & 9.7 & 0.14 & 27.2 \\
\hline & Treatment & 133 & 63 & 136 & 13.2 & 0.30 & 41.8 \\
\hline & Next day & 72 & 48 & 88 & 10.4 & 0.09 & 29.2 \\
\hline & Control & 93 & 68 & 107 & 10.5 & 0.11 & 26.4 \\
\hline \multirow{4}{*}{$\begin{array}{l}\text { Adrenal hyper- } \\
\text { plasia case D }\end{array}$} & Control & 138 & 74 & 137 & 10.1 & 0.27 & 32.0 \\
\hline & Treatment & 468 & 153 & 432 & 8.1 & 0.37 & 55.0 \\
\hline & Next day & 81 & 57 & 105 & 8.9 & 0.33 & 36.0 \\
\hline & Control & 81 & 42 & 85 & 6.8 & 0.21 & 35.0 \\
\hline
\end{tabular}

until the present illness which began at the age of 11 when he was a thin and energetic child. In the course of the next year he gained $50 \mathrm{lbs}$., developed a round "moon" ruddy face, purplish striae on the trunk, acne and excessive hair. The glucose tolerance was of a diabetic type but glycosuria did not occur. His blood pressure was 160/100. X-rays showed osteoporosis and a calculus in the right kidney. At the age of 12 a right ureterolithotomy and a left nephrolithotomy were performed. The adrenals were explored and found to be grossly normal. A biopsy showed hyperplasia of the reticular zone of the cortex. He was given 20 doses of 95 R.U. of radiation to the pituitary. In 1945 at the age of 14 he was readmitted and found to have a urinary excretion of $2.9 \mathrm{mg}$. of neutral reducing lipids and 27-37 mg. of 17-ketosteroids. He was then placed on $30 \mathrm{mg}$. methyl testosterone daily and the neutral reducing lipids fell to $0.58 \mathrm{mg}$., while the $17-$ ketosteroids fell to $12 \mathrm{mg}$. Treatment with methyl testosterone was continued up until the time of the present study, throughout the experiment and after discharge from the hospital. At the time of these studies the classical picture of Cushing's

TABLE IV

Effect of adrenocorticotrophic hormone upon blood chemistry

\begin{tabular}{|c|c|c|c|c|c|c|c|}
\hline Syndrome & Period & Sodium & Potassium & $\underset{\text { power }}{\mathrm{CO}_{2} \text { comb. }}$ & Chloride & Cholesterol & Sugar \\
\hline \multirow{3}{*}{$\begin{array}{l}\text { Cushing's } \\
\text { syndrome }\end{array}$} & Control & $\begin{array}{c}\text { m.eq./l. } \\
137.5\end{array}$ & $\begin{array}{c}m . e q . / l \\
4.7\end{array}$ & $\begin{array}{c}\text { m.eq./l. } \\
28.7\end{array}$ & $\begin{array}{c}m . e q . / l . \\
105.0\end{array}$ & $\begin{array}{c}m g . \% \\
375\end{array}$ & $\begin{array}{c}m 8 . \% \\
76\end{array}$ \\
\hline & Treatment & 136.6 & 5.0 & 27.0 & 102.3 & 327 & 118 \\
\hline & Control & 135.3 & 4.9 & 26.6 & 105.6 & 345 & 80 \\
\hline \multirow{3}{*}{$\begin{array}{l}\text { Adrenal hyper- } \\
\text { plasia case } \mathrm{B}\end{array}$} & Control & 136.0 & 3.9 & 25.0 & 110.2 & 177 & 84 \\
\hline & Treatment & 139.0 & 4.3 & 24.2 & 104.7 & 165 & 92 \\
\hline & Control & 133.5 & 4.4 & 26.2 & 102.0 & 160 & 104 \\
\hline \multirow{3}{*}{$\begin{array}{l}\text { Adrenal hyper- } \\
\text { plasia case D }\end{array}$} & Control & 137.5 & 3.8 & 26.6 & 104.0 & 120 & 88 \\
\hline & Treatment & 135.5 & 4.2 & 25.8 & 102.0 & 121 & 88 \\
\hline & Control & 141.5 & 3.8 & 27.0 & 102.2 & 125 & 80 \\
\hline
\end{tabular}


TABLE V

Hematological effects of adrenocorticotrophic hormone

\begin{tabular}{|c|c|c|c|c|c|c|}
\hline Syndrome & Period & Hematocrit & Leucocytes & $\begin{array}{l}\text { Polymorpho- } \\
\text { nuclears }\end{array}$ & Eosinophils & $\begin{array}{c}\text { Mononuclear } \\
\text { cells }\end{array}$ \\
\hline \multirow[t]{3}{*}{ Cushing's syndrome } & Control & $\begin{array}{l}m m . \\
47.2\end{array}$ & $\begin{array}{c}\text { per } \mathrm{cmm} . \\
5,400\end{array}$ & $\begin{array}{c}\text { per cent } \\
69\end{array}$ & $\begin{array}{c}\text { per cent } \\
3\end{array}$ & $\begin{array}{c}\text { per cent } \\
28\end{array}$ \\
\hline & Treatment & 49.0 & 14,400 & 87 & 1 & 12 \\
\hline & Control & 48.0 & 9,150 & 67 & 0 & 32 \\
\hline \multirow{3}{*}{$\begin{array}{l}\text { Adrenal hyperplasia } \\
\text { case B }\end{array}$} & Control & 43.5 & 6,400 & .35 & 0 & 65 \\
\hline & Treatment & 45.7 & 9,800 & 56 & 5 & 39 \\
\hline & Control & 45.4 & 5,600 & 28 & 9 & 63 \\
\hline \multirow{3}{*}{$\begin{array}{l}\text { Adrenal hyperplasia } \\
\text { case D }\end{array}$} & Control & 36.8 & 3,850 & 49 & 1 & 50 \\
\hline & Treatment & 37.8 & 6,900 & 53 & 2 & 45 \\
\hline & Control & 34.8 & 6,800 & 44 & 8 & 48 \\
\hline
\end{tabular}

syndrome had not changed materially although there had been no apparent progress of the disease. The weight was $133 \mathrm{lbs}$. and the height 55.3 inches. Obesity and dull red striae were still present. The blood pressure was $150 / 100$. The testes measured only $1.8 \times 3 \mathrm{~cm}$. X-rays showed a bone age of 15 years and slight osteoporosis. The laboratory data are given in Tables II-V.

Congenital adrenal hyperplasia with female pseudohermaphroditism. Case $B$. The patient $(H$. L. H. A 47344) was a girl aged $61 / 2$ years. Mother, father and a younger sister are alive and well. General health excellent except for the present illness and an attack of measles one month before this hospitalization. Enlarged clitoris and absence of a vaginal orifice was noted at birth and pubic hair appeared at the age of three. At five she was found to have a height age of seven and a bone age of 11 with an I.Q. of 120 . The clitoris was amputated and a urogenital sinus was demonstrated. At the time of these studies the weight was $63 \mathrm{lbs}$. and the height 56 inches. There was abundant pubic and axillary hair and the voice was deep. There was marked acne and seborrhea. The laboratory data are shown in Tables II-V.

Congenital adrenal hyperplasia with female pseudohermaphroditism. Case $D$. The patient (H. L. H. A 30453) was a girl aged $6 \frac{1}{2}$ years. Mother and father are well and a younger sister is quite normal but two younger brothers have adrenal hyperplasia with precocious secondary sexual development but small testes. At the age of 12 days a diagnosis of pseudohermaphroditism was made. At the age of 19 months a urogenital sinus was demonstrated and a laparotomy performed. This revealed normal uterus and ovaries and normal sized adrenals. At the age of five years pubic hair appeared. At the time of these studies the weight was $59 \mathrm{lbs}$. and the height 55.5 inches. There was abundant pubic and axillary hair and the voice was unusually deep. There was no pigmentation although the skin was tan in color. Laboratory examinations are shown in Tables II-V.

\section{RESULTS}

From Table II it may be seen that there was very slight rise in the blood pressure of the two cases of adrenal hyperplasia, and no rise in the case of the treated Cushing's syndrome until the day after treatment was completed. There was little change in the pulse rate and no febrile response. The girls with adrenal hyperplasia lost .3 to $.4 \mathrm{~kg}$. of weight during the 24 -hour treatment period while the boy with Cushing's syndrome gained approximately the same amount, $.3 \mathrm{~kg}$. The fluid intake was not constant nor accurately measured. There was no consistent change in the metabolic rate of the girls with adrenal hyperplasia, while there was a slight rise in the case of Cushing's syndrome.

The rise in excretion of neutral reducing lipids, Table III, in the cases of adrenal hyperplasia was small, from .27 to $.37 \mathrm{mg}$. per 24 hours in one case, and from .14 to $.30 \mathrm{mg}$. per 24 hours in the other, while in the case of Cushing's syndrome the rise was more marked and lasted longer. It averaged .33 during the control period and rose to 1.06 on the day of treatment, remained at .69 the next day and then averaged $.33 \mathrm{mg}$. per 24 hours for the next three days. The fall in respiratory quotient in the cases of adrenal hyperplasia was also less marked than in the case of Cushing's syndrome. In the latter, the respiratory quotient dur- 
ing the control period averaged .85 , immediately after treatment fell to .76 , rose to .89 the next day and then averaged .90 the next three days.

There was no rise in the fasting blood sugar in the cases of adrenal hyperplasia, but in the boy with Cushing's syndrome the fasting level of 76 mg. \% was increased to $116 \mathrm{mg}$. \% after the injection of adrenocorticotrophic hormone, and fell again the next day to $80 \mathrm{mg}$. \%, Table IV. The urinary excretion of nitrogen remained relatively constant except in one of the cases of adrenal hyperplasia where there was an increase on the day of treatment.

Although the daily excretion of 17 -ketosteroids before treatment was much higher in the girls with adrenal hyperplasia and virilism than in the case of Cushing's syndrome, following adrenocorticotrophic hormone there was also a greater rise in the urinary output, i.e., from 27 to $42 \mathrm{mg}$. in one case, and from 32 to $55 \mathrm{mg}$. in the other. The rise in the case of Cushing's syndrome persisted for a longer time, the excretion being 10.4 mg. daily during the control period, 24.4 on the day of treatment, 20.2 the next day and then averaging $8.3 \mathrm{mg}$. for the next three days.

There was a moderate increase in the excretion of potassium on the day of treatment in the case of Cushing's syndrome and in one of the cases of adrenal hyperplasia. All three cases showed a decreased potassium excretion on the day following treatment.

The boy with Cushing's syndrome showed a very marked retention of sodium on the day of treatment, an effect which carried over to the next. day. The sodium excretion during the control period averaged 142 m.eq. per day, fell to 39 m.eq. on the day of treatment, remained at 38 m.eq. the next day, and then rose to 133 m.eq. a day for the last three days of the experiment. This retention of sodium was so marked that there was a decrease in the chloride excretion despite the rise in potassium excretion.

On the other hand, both cases of adrenal hyperplasia with virilism showed an increased excretion of sodium on the day of treatment. In one of the cases the sodium excretion rose from $138 \mathrm{~m}$.eq. a day to $468 \mathrm{~m} . e q$. on the day of treatment and dropped to $81 \mathrm{~m}$.eq. a day for the following four days. With the increased sodium excretion there was also an increase in the chloride excretion. The girl who showed the marked sodium and chloride diuresis manifested a slight drop in serum sodium and chloride, from 137.5 to 135.5 m.eq. per 1 . and from 104.0 to 102.0 m.eq. per 1. respectively.

Only in the case of Cushing's syndrome was there a significant change in the serum cholesterol which fell from 375 to $327 \mathrm{mg}$. \%, and then rose to $345 \mathrm{mg}$. \%. In this case the total serum fat also fell from 1120 to $1070 \mathrm{mg}$. \%, and then rose to $1250 \mathrm{mg}$. $\%$.

All three cases showed a slight rise in the total white blood cell count and a shift from mononuclear to polymorphonuclear cells, Table V. The boy with Cushing's.syndrome manifested a fall in the percent of eosinophils at the end of the treatment period, while the two girls showed a delayed rise in the eosinophil count when it was taken during the post treatment period. The eosinophil percentage was determined by blood smears rather than by direct count so that minor changes are not significant.

\section{DISCUSSION}

The boy with treated Cushing's syndrome responded to the injections of adrenocorticotrophic hormone in much the same fashion as a normal individual $(1,2)$. The rise in 17 -ketosteroid and neutral reducing lipid excretion was of approximately the same magnitude and duration (two days) as with normal individuals. It should be noted at this point that this patient had received pituitary radiation in the past and was given 30 mg. methyl testosterone daily for two years prior to hospitalization. This medication was continued throughout the experiment. Whether this patient was in partial remission or merely kept under control by the administration of methyl testosterone cannot be determined with certainty.

The sodium retention and gain in weight despite the potassium diuresis are similar to the phenomena which occur in normal individuals given adrenocorticotrophic hormone.

The increase in fasting blood sugar observed in this case is similar to that reported in normal individuals although in this instance glycosuria did not occur. McAlpine has pointed out that when glycosuria is produced the excretion of glucose is greater than could be accounted for by the increased excretion of nitrogen so that he suggested that the adrenocorticotrophic hormone might pro- 
duce a decrease in the oxidation of glucose as well as an increase in the amount of gluconeogenesis (2). The fall in respiratory quotient observed in this case of Cushing's syndrome following the administration of adrenocorticotrophic hormone suggests that there may have been a decrease in the utilization of glucose or a relative increase in the utilization of fats.

The effects of adrenocorticotrophic hormone in the cases of congenital adrenal hyperplasia with pseudohermaphroditism differ in certain respects from those found by us in the patient with Cushing's syndrome, or those reported in normal and hypopituitary individuals. In the cases of adrenal hyperplasia of the androgenic type, this hormone caused a moderate or marked increase in the renal excretion of sodium instead of a sodium retention which is usually found. It is believed that this represents the first clearcut example of a trophic hormone producing a qualitatively different effect upon the same endocrine gland and suggests that the secretory activity of the adrenal in cases of congenital adrenal hyperplasia with virilism differs qualitatively from that of other conditions.

The explanation of the sodium loss is not entirely clear. In a preliminary discussion (11) it was suggested that in patients with congenital adrenal hyperplasia associated with Addisonian crises the adrenal glands might secrete steroids which promote sodium excretion rather than sodium retention. It is known that the compounds 17-hydroxycorticosterone and 17-hydroxy-11-dehydrocorticosterone promote the excretion rather than the retention of sodium (12). The fact that adrenocorticotrophic hormone did not cause as great a rise in the excretion of neutral reducing lipids in the cases of adrenal hyperplasia with virilism as it did in the case of Cushing's syndrome does not prove or disprove this hypothesis. The marked increase in the production of 17-ketosteroids is compatible with the fact that the clinical findings in these cases are principally due to excessive androgen.

\section{SUM MARY}

Adrenocorticotrophic hormone, equivalent to 83 mg. of the standard preparation, was administered over a 24-hour period to one case of Cushing's syndrome being treated with methyl testosterone and two cases of congenital adrenal hyperplasia with virilism.

The Cushing's syndrome showed a rise in the renal excretion of 17 -ketosteroids and neutral reducing lipids, a rise in the fasting blood sugar, a fall in the respiratory quotient, a polymorphonuclear leukocytosis, an increase in the excretion of potassium and a marked reduction in the excretion of sodium accompanied by a slight temporary gain in weight.

The two cases of congenital adrenal hyperplasia with virilism showed a marked rise in the renal excretion of 17 -ketosteroids and only a slight rise in the renal excretion of neutral reducing lipids. There was no rise in fasting blood sugar, slight fall in the respiratory quotient, and a polymorphonuclear leukocytosis. There was a moderate to marked increase rather than decrease in sodium excretion with a slight temporary loss rather than gain in weight.

\section{ACKNOWLEDGMENT}

The assistance of Miss Lee Helfgott and Miss June Hunt in performing the steroid determinations is gratefully acknowledged.

The assistance of Dr. R. L. McLean and Miss M. E. Keavney who performed the gas analyses is gratefully acknowledged.

The assistance of $\mathrm{Mr}$. H. Eisenberg in performing the sodium and potassium determinations is also gratefully acknowledged.

\section{BIBLIOGRAPHY}

1. Forsham, P. H., Thorn, G. W., Prunty, F. T. G., and Hills, A. G., Clinical studies with pituitary adrenocorticotropin. J. Clin. Endocrinol., 1948, $8,15$.

2. Browne, J. S., Johnson, L. G., and McAlpine, H., Some effects of large doses of adrenocorticotrophic hormone. Tr. 17th Conference on Metabolic Aspects of Convalescence, March 28-9, 1948.

3. Mason, H. L., Power, M. H., Rynearson, E. H., Ciaramelli, L. C., Li, C. H., and Evans, H. M., Results of administration of anterior pituitary adrenocorticotrophic hormone to a normal human subject. J. Clin. Endocrinol., 1948, 8, 1.

4. Albright, F., Forbes, A. P., and Bartter, F. C., The number of adrenocorticotrophic hormones in man. Tr. 17th Conference on Metabolic Aspects of Convalescence, March 28-9, 1948.

5. Scholander, P. F., Analyzer for accurate estimation of respiratory gases in one-half cubic centimeter samples. J. Biol. Chem., 1947, 167, 235.

6. Callow, N. H., Callow, R. K., and Emmens, C. W., Colorimetric determination of substances contain- 
ing the grouping $-\mathrm{CH}_{2}-\mathrm{CO}-$ in urine extracts as an indication of androgen content. Biochem. J., 1938, 32, 1312.

7. Heard, R. D. H., and Sobel, H., Steroids, VIII. A colorimetric method for the estimation of reducing steroids. J. Biol. Chem., 1946, 165, 687.

8. Talbot, N., Saltzman, A. H., Wixom, R. L., and Wolfe, J. K., The colorimetric assay of urinary corticosteroid-like substances. J. Biol. Chem., 1945, $160,535$.

9. Peters, J. P., and Van Slyke, D. D., Quantitative Clinical Chemistry, Vol. II. Williams and Wilkins Co., Baltimore, 1932.
10. Howard, J. E., and Bigham, R. S., Jr., Potassium determinations by flame photometer. Tr. 11th Conference on Metabolic Aspects of Convalescence, Oct. 15-16, 1945, 9.

11. Wilkins, L., and Lewis, R. A., The renal excretion of steroid hormones in pseudohermaphroditism and male sexual precocity associated with symptoms of Addison's disease. Tr. 17th Conference on Metabolic Aspects of Convalescence, March 28-9, 1948.

12. Thorn, G. W., Engel, L. L., and Lewis, R. A., The effect of 17-hydroxycorticosterone and related adrenal cortical steroids on sodium and chloride excretion. Science, 1941, 94, 348. 